\title{
Chemical and sensory properties of complementary food produced from sorghum (Sorghum bicolor I), pigeon pea (Cajanus cajan) and carrot (Daucus carrota) blends
}

\author{
${ }^{1}$ Okudu, H.O, ${ }^{2}$ Ojinnaka, M.C and ${ }^{1}$ Kalu, M.O \\ ${ }^{1}$ Department of Human Nutrition and Dietetics Michael Okpara University of Agriculture Umudike, Abia State \\ ${ }^{2}$ Department of Food Science and Technology Michael Okpara University of Agriculture Umudike, Abia State \\ ${ }^{*}$ Corresponding Author's E-mail: helenokudu@yahoo.com, Tel: +2340869189948
}

\begin{abstract}
The work was designed to develop a complementary food from sorghum, pigeon pea and carrot flour blends. The proximate and vitamin content of the samples were determined using standard AOAC methods. Mineral elements were determined using wet-acid digestion method for multiple nutrients determination. Means and standard deviation were calculated and compared using ANOVA. The chemicals and sensory properties were compared to those of cerelac. Ccerelac had significantly $(p<0.05)$ higher protein $(5.31 \%)$ and fat $(3.93 \%)$. Sorghum:Pigeon pea:Carrot $(50: 20: 30)$ had significantly higher fiber $(0.17 \%)$ and ash $(1.08 \%)$ while Sorghum:Pigeon pea:Carrot (50:30:20) was significantly higher in carbohydrate and energy $(27.25 \mathrm{~g} / 100 \mathrm{~g}$ and $159 \mathrm{kcal} / \mathbf{1 0 0 \mathrm { g }})$. Minerals of significant amounts in the products were $P(213.22-216.86 \mathrm{mg} / 100 \mathrm{~g}), \mathrm{K}(191.32-$ $194.63 \mathrm{mg} / 100 \mathrm{~g})$, and $\mathrm{Zn}(88.8-93 \mathrm{mcg} / 100 \mathrm{~g})$. $\beta$-carotene $(7280 \mathrm{mcg} / 100 \mathrm{~g})$ and vitamin $C(4.78 \mathrm{mg} / 100 \mathrm{~g})$ were significantly higher in S:P:C (50:20:30), while tecopherol $(3.16 \mathrm{mg} / 100 \mathrm{~g})$, riboflavin $(0.29 \mathrm{mg} / 100 \mathrm{~g})$, niacin $(3.93 \mathrm{mg} / 100 \mathrm{~g})$, pyrodixine $(0.63 \mathrm{mg} / 100 \mathrm{~g})$ and cyanocobalamin $(0.24 \mathrm{mg} / 100 \mathrm{~g})$. No phytochemical was detected in cerelac, in the blends all phytochemical assessed were below $1 \%$. Sensory evaluation showed that cerelac was better accepted in terms of colour, texture, taste and flavor than the blends. Though the blends were not as acceptable as cerelac chemical test however showed that S:P:C (50:20:30) was richer in key nutrients such as $\beta$-carotene and vitamin $C$ than cerelac.
\end{abstract}

Keywords: complementary food, sorghum, pigeon pea, carrot, $\beta$-carotene

\section{INTRODUCTION}

Breast milk has been proven to be a complete and perfect food for infants during the first six (6) months of life (Luther and Rivera, 2003); after which it will no longer be sufficient both in term of quality and quantity to meet the nutritional requirement on the infant (UNICEF. 2009). Complementary food that has adequate nutrient and safety has become a priority for nutrition of infants and young children because of its role in preventing mortality and enhancing children development (Lutter and Dewey, 2003). It is however unfortunate that many families still depend on inadequately processed traditional food consisting of un-supplemented cereal porridge made from maize, sorghum and millet (Nnam, 2002). These traditional complementary foods are affordable in most cases but are grossly deficient in most key nutrients. The key nutrients include protein, calcium, iron, zinc and vitamin A (Brown, 1991). An early consequences of inadequate intake of these nutrients as a result of suboptimal levels in infant foods manifest in form of growth faltering and late brain development (Uvere et al., 2008). For those that supplement complementary foods with legume such as soybean, groundnut, cowpea, and of recent pigeon pea; the complementary food is often deficient in $\beta$-carotene. B-carotene is a precursor of vitamin $A$. The role of vitamin A in child's physical and mental development is well documented. This work is designed to develop complementary food from sorghum, pigeon pea and carrot using the principle of food -to-food fortification. 


\section{MATERIALS AND METHODS}

\section{Procurement of samples}

Sorghum (Sorghum bicolor L) and pigeon pea (Cajanus cajan) was purchased in Nsukka Main Market Enugu State. Carrot was purchased in Umuahia Market in Abia State

\section{Cleaning /Production of sorghum (Sorghum bicolor L.) flour}

Foreign materials and broken seeds were sorted manually. One kilogram $(1 \mathrm{~kg})$ sorghum was soaked in potable water at room temperature $\left(29 \pm 2^{\circ} \mathrm{C}\right)(2: 1$ water: sorghum) for $24 \mathrm{hr}$, after which the water was discarded and the sample washed with clean water. The sample was oven dried at $72^{\circ} \mathrm{C}$ for $4 \mathrm{hrs}$ and then toasted on an open gas cooker with moderate heating for 30mins. Toasted sorghum was milled using hammer milling machine (Model E d - 5 Thomas Wily; England), and sifted with muslin cloth. The flour was stored in an air tight container at room temperature prior to blend formulation.

\section{Cleaning/Production of Pigeon pea (Cajanus cajan) flour}

A kilogram of cleaned and sorted soybean was soaked in water at the ratio of 2:1 (water/pigeon pea) overnight. The out covering was removed by hand rubbing. Cleaned seeds were then steamed for 45 minutes and oven dried at $72^{\circ} \mathrm{C}$ for $6 \mathrm{hr}$. the seed was toasted for 30 mi nutes and then milled using hammer milling machine (Model E d - 5 Thomas Wily; England), and sifted with muslin cloth. The flour was stored in an air tight container at room temperature prior to blend formulation.

\section{Cleaning/Production of carrot flour}

Five hundred gram manually scrapped and washed carrots were cut into cubes of about $0.5 \mathrm{~cm}$. The sliced carrots were blanched for $5 \mathrm{~min}$ using water of $90^{\circ} \mathrm{C}$. The water was drained off and the carrot was oven dried at $60^{\circ} \mathrm{C}$ for $12 \mathrm{hr}$. The dried carrot was dry milled using hammer milling machine (Model E d - 5 Thomas Wily; England) then stored in an air tight plastic container at room temperature prior to blend formulations.

Formulation of blends from sorghum, pigeon pea and carrot flour for the production of complementary food

Blends were formulated based on the protein composition of processed flour (Nnam and Odigwe, 2007) in ratios of $60: 40: 0, \quad 70: 20: 10$ and 50:30:20 (protein basis) of sorghum, pigeon pea and carrot.

\section{Preparation of gruel from sorghum, pigeon pea and carrot flour}

Slurry was made by mixing two hundred gram of each of the blend with $400 \mathrm{ml}$ of water. The slurry was allowed to rest for 10 minutes at room temperature $\left(29-30{ }^{\theta} \mathrm{C}\right)$ to allow for proper water absorption. The slurry was then gradually poured in a pot of boiling water $(600 \mathrm{ml})$ with continuous stirring until a thick paste was formed. Twenty gram of granulated sugar was added to each paste.

\section{Chemical analyses}

The proximate compositions of the sample were determined using AOAC (2006) methods. Moisture content of the jam was determined gravimetrically. The protein content was determined by micro- Kjeldahl method, using 6.25 as the nitrogen conversion factor. The fat content was determined by Soxhlet extraction method using petroleum ether. The ash content was determined by incinerating the samples at $600{ }^{\circ} \mathrm{C}$ in a muffle furnace. Carbohydrate was obtained by difference, while gross energy (KJ and Kcal per $100 \mathrm{~g}$ ) was calculated based on the formula by Eknayake et al. (1999). Gross energy (Kcal per $100 \mathrm{~g}$ dry matter $)=$ (crude protein $\times 17)+($ crude lipid $\times 37)+$ (crude carbohydrate $x$ 17) for protein, carbohydrate and lipid, respectively.

Mineral elements were determined using wet-acid digestion method for multiple nutrients determination as described by the method of AOAC (2006). About $0.2 \mathrm{~g}$ of the processed sample material was weighed into a 150 $\mathrm{ml}$ Pyrex conical flask. Five milliliters $(5 \mathrm{ml})$ of the extracting mixture $\left(\mathrm{H}_{2} \mathrm{SO}_{4}-\right.$ Sodium salicylic acid) was added to the sample. The mixture was allowed to stand for $16 \mathrm{~h}$. The mixture was then placed on a hot plate set at $30^{\circ} \mathrm{C}$ and allowed to heat for about $2 \mathrm{~h}$. Five mil liliters $(5 \mathrm{ml})$ of concentrated perchloric acid was introduced to the sample and heated vigorously until the sample was digested to a clear solution. Twenty milliliters of distilled $\mathrm{H}_{2} \mathrm{O}$ was added and heated to mix thoroughly for about a minute. The digest was allowed to cool and was transferred into a $50 \mathrm{ml}$ volumetric flask and made up to the mark with distilled water. The digest was used for the determinations of calcium $(\mathrm{Ca})$ and magnesium $(\mathrm{Mg})$ by the ethylenediamine ditetraacetic acid Versanate Complexiometric titration method (AOAC, 2006). AOAC (2006) method was used to determine sodium $(\mathrm{Na})$ and potassium (K) by using a flame photometer (model PFP7 Digital, Jenway, UK). All other minerals were determined by atomic absorption spectrophotometer (model 3030, Perkin Elmer, Norwalk USA). 
052 Afr. J. Food Sci. Technol.

Table 1.Energy and proximate composition of gruel produced from cerelac and sorghum, pigeon pea and carrot blends.

\begin{tabular}{|c|c|c|c|c|}
\hline Nutrient & $S: P(60: 40)$ & S:P:C (50:20:30) & S:P:C (50:30:20) & Cerelac \\
\hline Moisture $(\mathrm{g} / 100 \mathrm{~g})$ & $79.34^{a} \pm 0.12$ & $71.60^{\circ} \pm 0.00$ & $64.34^{\mathrm{d}} \pm 0.06$ & $69.27^{\circ} \pm 0.04$ \\
\hline Crude protein $(\mathrm{g} / 100 \mathrm{~g})$ & $4.72^{b} \pm 0.00$ & $4.53^{\mathrm{c}} \pm 0.00$ & $4.54^{\mathrm{c}} \pm 0.08$ & $5.31^{a} \pm 0.14$ \\
\hline Crude fat $(g / 100 \mathrm{~g})$ & $2.81^{\mathrm{b}} \pm 0.14$ & $2.74^{\mathrm{C}} \pm 0.00$ & $2.67^{\mathrm{d}} \pm 0.02$ & $3.93^{\mathrm{a}} \pm 0.01$ \\
\hline Crude fiber $(\mathrm{g} / 100 \mathrm{~g})$ & $0.12^{c} \pm 0.00$ & $0.17^{\mathrm{a}} \pm 0.02$ & $0.14^{\mathrm{ab}} \pm 0.00$ & $0.14^{\mathrm{ab}} \pm 0.01$ \\
\hline Ash $(\mathrm{g} / 100 \mathrm{~g})$ & $0.93^{c} \pm 0.01$ & $1.08^{\mathrm{a}} \pm 0.02$ & $1.07^{\mathrm{ab}} \pm 0.02$ & $1.03^{\mathrm{b}} \pm 0.01$ \\
\hline $\mathrm{CHO}(\mathrm{g} / 100 \mathrm{~g})$ & $12.09^{\mathrm{d}} \pm 0.09$ & $19.89^{c} \pm 0.04$ & $27.25^{\mathrm{a}} \pm 0.07$ & $20.33^{\mathrm{b}} \pm 0.08$ \\
\hline Energy (kcal/kJ) & $92.53 / 389.74$ & $122.34 / 456.52$ & $151.19 / 639.22$ & $137.93 / 581.29$ \\
\hline
\end{tabular}

Values are mean \pm standard deviation of duplicate samples

${ }^{a-d}$ Means with similar superscript are not significantly difference $(P>0.05)$

Note: S:P $(60: 40)=$ sorghum 60 : pigeon pea 40

S:P:C $(50: 20: 30)=$ sorghum 50: pigeon pea 20: $\operatorname{carrot} 30$

$S: P: C(50: 30: 20)=$ sorghum 50: pigeon pea $30:$ carrot 20

The $\beta$-carotene, riboflavin, niacin and thiamin of the products were determined spectrophotometrically as described by AOAC (2006). Ascorbic acid was determined using titration method as described by AOAC (2006). Gravimetric method (AOAC, 2006) was used to determine alkaloids. Saponin was determined by gravimetric oven drying method as described by the method of AOAC (2006). Tannin content of the sample was determined spectrophometrically as described by Kirk and Sawyer (1991).

\section{Sensory evaluation}

Sensory evaluation of the products was carried out by a group of 20 panelists made of nursing mothers. Cerelac was used as the control. The evaluation was carried out in the food laboratory of the Department of Home economics. The judges evaluated the products using a seven point hedonic scale where 7 = like very much and 1 = dislike very much. Panelists scored the sample for four sensory attributes - colour, flavor, taste and over all acceptability. A cup of potable water was given to the panelist to rinse his/her mouth after each tasting.

\section{Statistical analysis}

Data were expressed as means \pm standard deviation (SD) of two replications, and one factor ANOVA was used for the statistical analysis using SPSS program (version 20 SPSS Inc., USA). The values of sensory evaluation were considered to be significantly different when $\mathrm{P}<0.05$.

\section{RESULTS}

Energy and proximate composition of the gruel produced from sorghum pigeon pea and carrot blends.

The result of energy and proximate composition of gruel made from sorghum, pigeon pea, carrot blends and cerelac is shown is shown on Table 1. Moisture was relatively high in all the products. Moisture ranged between $64.34-79.34 \%$ in the blends while in cerelac moisture obtained was $69.27 \%$. Protein and fat (5.31 and $3.93 \%$ respectively) in cerelac were significantly $(p<0.05)$ than those of the blends (4.53 - $4.72 \%$ and $2.67-2.81 \%$ respectively). Carbohydrate and energy values (27.25\% and 151kcal) of Sorghum: Pigeon pea: Carrot (50:30:20) were higher than those of the other products.

\section{Mineral composition of the gruels from cerelac and sorghum, pigeon pea and carrot blends}

The macro - mineral composition of the products is shown on Table 2. The predominant macro-mineral obtained in this study were phosphorus and potassium. The potassium and phosphorus content (278.62 and $218.36 \mathrm{mg} / 100 \mathrm{~g}$ respectively) of cerelac were significantly higher than those of the blends $(213.72-216.86$ and $191.32-194.63 \mathrm{mg} / 100 \mathrm{~g}$ respectively). Calcium and magnesium obtained for cerelac were 32.79 and $16.72 \mathrm{mg} / 100 \mathrm{~g}$ respectively while those of the blends were $24.92-27.34 \mathrm{mg} / 100 \mathrm{~g}$ and $12.70-13.56 \mathrm{mg} / 100 \mathrm{~g}$ respectively.

The microminerals results on Table 2 show that iron content of cerelac was $3.61 \mathrm{mg} / 100 \mathrm{~g}$ while those of the blends ranged between $2.47-2.78 \mathrm{mg} / 100 \mathrm{~g}$. It was observed that the iron content of cerelac $(3.61 \mathrm{mg} / 100 \mathrm{~g})$ was not significantly $(p>0.05)$ different from that $(2.78 \mathrm{mg} / 100 \mathrm{~g})$ of sorghum:pigeon pea:carrot $(\mathrm{S}: \mathrm{P}: \mathrm{C})$ $(60: 40: 0)$. Zinc, selenium and iodine contents of cerelac $(2.74, \quad 3.58$ and $12.46 \mathrm{mg} / 100 \mathrm{~g}$ respectively) were significantly higher than the zinc, selenium and iodine contents of the blends $(1.82-2.16 \mathrm{mg} / 100 \mathrm{~g}, 21.6$ $27.6 \mathrm{mcg} / 100 \mathrm{~g}$ and $88.7-93.2 \mathrm{mcg} / 100 \mathrm{~g}$ respectively).

Vitamin composition of the gruels from cerelac and sorghum, pigeon pea and carrot blends

Vitamin results on Table 3 show that blends with carrot flour had higher $\beta$ - carotene, ascorbic and thiamin values 
Table 2. Mineral composition of the gruels from cerelac and sorghum, pigeon pea and carrot blends

\begin{tabular}{lllll}
\hline Nutrient & S:P (60:40) & S:P:C (50:20:30) & S:P:C (50:30:20) & Cerelac \\
\hline $\mathrm{Ca}(\mathrm{mg} / 100 \mathrm{~g})$ & $27.34^{\mathrm{b}} \pm 0.08$ & $25.41^{\mathrm{c}} \pm 0.14$ & $24.92^{\mathrm{d}} \pm 0.00$ & $32.79^{\mathrm{a}} \pm 0.01$ \\
$\mathrm{Mg}(\mathrm{mg} / 100 \mathrm{~g})$ & $12.70^{\mathrm{d}} \pm 0.14$ & $13.56^{\mathrm{b}} \pm 0.07$ & $13.26^{\mathrm{c}} \pm 0.03$ & $16.72^{\mathrm{a}} \pm 0.03$ \\
$\mathrm{P}(\mathrm{mg} / 100 \mathrm{~g})$ & $216.86^{\mathrm{b}} \pm 0.08$ & $215.49^{\mathrm{c}} \pm 0.30$ & $213.72^{\mathrm{d}} \pm 0.17$ & $278.62^{\mathrm{a}} \pm 0.03$ \\
$\mathrm{~K}(\mathrm{mg} / 100 \mathrm{~g})$ & $194.63^{\mathrm{b}} \pm 0.04$ & $193.82^{\mathrm{c}} \pm 0.03$ & $191.32^{\mathrm{d}} \pm 0.16$ & $218.36^{\mathrm{a}} \pm 0.08$ \\
$\mathrm{Fe}(\mathrm{mg} / 100 \mathrm{~g})$ & $2.78^{\mathrm{a}} \pm 0.00$ & $2.61^{\mathrm{c}} \pm 0.01$ & $2.47^{\mathrm{d}} \pm 0.02$ & $3.61^{\mathrm{a}} \pm 0.01$ \\
$\mathrm{Zn}(\mathrm{mg} / 100 \mathrm{~g})$ & $2.16^{\mathrm{b}} \pm 0.00$ & $1.85^{\mathrm{c}} \pm 0.00$ & $1.82^{\mathrm{d}} \pm 0.00$ & $2.74^{\mathrm{a}} \pm 0.00$ \\
$\mathrm{Se}(\mathrm{mcg} / 100 \mathrm{~g})$ & $27.6^{\mathrm{b}} \pm 0.03$ & $23.9^{\mathrm{c}} \pm 0.01$ & $21.6^{\mathrm{d}} \pm 0.00$ & $35.8^{\mathrm{a}} \pm 0.03$ \\
I (mcg/100g) & $93.2^{\mathrm{b}} \pm 0.11$ & $88.8^{\mathrm{c}} \pm 0.03$ & $84.7^{\mathrm{d}} \pm 0.02$ & $124.6^{\mathrm{a}} \pm 0.23$ \\
\hline
\end{tabular}

Values are mean \pm standard deviation of duplicate samples

a-d Means with similar superscript are not significantly difference $(P>0.05)$

Note: S:P $(60: 40)=$ sorghum 60: pigeon pea 40

$S: P: C(50: 20: 30)=$ sorghum $50:$ pigeon pea $20:$ carrot 30

S:P:C $(50: 30: 20)=$ sorghum 50: pigeon pea $30: \operatorname{carrot} 20$

Table 3. Vitamin composition of the complementary gruels from sorghum, pigeon pea and carrot

\begin{tabular}{|c|c|c|c|c|}
\hline Nutrient & S:P (60:40) & S:P:C (50:20:30) & S:P:C (50:30:20) & Cerelac \\
\hline$\beta$. carotene $(\mathrm{mcg} / 100 \mathrm{~g})$ & $4930^{d} \pm 0.01$ & $7280^{a} \pm 0.00$ & $7150^{D} \pm 0.00$ & $5220^{C} \pm 0.03$ \\
\hline Ascorbic acid $(\mathrm{mg} / 100 \mathrm{~g})$ & $3.48^{\mathrm{d}} \pm 0.00$ & $4.78^{\mathrm{a}} \pm 0.03$ & $4.27^{\mathrm{b}} \pm 0.02$ & $4.08^{\mathrm{C}} \pm 0.02$ \\
\hline Tecopherol $(\mathrm{mg} / 100 \mathrm{~g})$ & $2.85^{\mathrm{C}} \pm 0.01$ & $2.91^{\mathrm{ab}} \pm 0.01$ & $2.88^{\mathrm{b}} \pm 0.03$ & $3.16^{\mathrm{a}} \pm 0.02$ \\
\hline Thiamin $(\mathrm{mg} / 100 \mathrm{~g})$ & $0.49^{c} \pm 0.01$ & $0.56^{\mathrm{a}} \pm 0.00$ & $0.52^{b} \pm 0.00$ & $0.50^{\mathrm{C}} \pm 0.00$ \\
\hline Riboflavin (mg/100q) & $0.19^{b} \pm 0.00$ & $0.24^{\mathrm{ab}} \pm 0.01$ & $0.22^{b} \pm 0.03$ & $0.29^{\mathrm{a}} \pm 0.02$ \\
\hline Niacin $(\mathrm{mg} / 100 \mathrm{~g})$ & $3.44^{\mathrm{C}} \pm 0.02$ & $3.61^{b} \pm 0.01$ & $3.44^{\mathrm{C}} \pm 0.02$ & $3.93^{\mathrm{a}} \pm 0.01$ \\
\hline Pyridoxine $(\mathrm{mg} / 100 \mathrm{~g})$ & $0.48^{d} \pm 0.00$ & $0.53^{b} \pm 0.00$ & $0.50^{c} \pm 0.00$ & $0.63^{\mathrm{a}} \pm 0.01$ \\
\hline $\begin{array}{l}\text { Cyanocobalamin } \\
\text { (mg/100g) }\end{array}$ & $0.15^{\mathrm{c}} \pm 0.00$ & $0.18^{b} \pm 0.00$ & $0.18^{\mathrm{b}} \pm 0.00$ & $0.24^{\mathrm{a}} \pm 0.01$ \\
\hline
\end{tabular}

Values are mean \pm standard deviation of duplicate samples

${ }^{a-d}$ Means with similar superscript are not significantly difference $(P>0.05)$

Note: S:P $(60: 40)$ = sorghum 60: pigeon pea 40

$S: P: C(50: 20: 30)=$ sorghum $50:$ pigeon pea 20 : carrot 30

$S: P: C(50: 30: 20)=$ sorghum 50 : pigeon pea $30:$ carrot 20

Table 4. Phytochemical composition of the gruels from cerelac and sorghum, pigeon pea and carrot blends $(\mathrm{g} / 100 \mathrm{~g})$.

\begin{tabular}{lllll}
\hline Nutrient & S:P (60:40) & S:P:C (50:20:30) & S:P:C (50:30:20) & Cerelac \\
\hline Tannin & $0.07^{\mathrm{b}} \pm 0.00$ & $0.09^{\mathrm{b}} \pm 0.00$ & $0.09^{\mathrm{a}} \pm 0.00$ & $0.00^{\mathrm{c}} \pm 0.00$ \\
Flavonoid & $0.04^{\mathrm{c}} \pm 0.00$ & $0.07^{\mathrm{a}} \pm 0.00$ & $0.07^{\mathrm{b}} \pm 0.00$ & $0.00^{\mathrm{d}} \pm 0.00$ \\
Phytate & $0.05^{\mathrm{a}} \pm 0.00$ & $0.05^{\mathrm{ab}} \pm 0.00$ & $0.05^{\mathrm{b}} \pm 0.00$ & $0.00^{\mathrm{c}} \pm 0.00$ \\
Oxalate & $0.03^{\mathrm{a}} \pm 0.00$ & $0.03^{\mathrm{a}} \pm 0.00$ & $0.02^{\mathrm{b}} \pm 0.00$ & $0.00^{\mathrm{c}} \pm 0.00$ \\
Alkaloid & $0.06^{\mathrm{a}} \pm 0.00$ & $0.05^{\mathrm{b}} \pm 0.00$ & $0.04^{\mathrm{c}} \pm 0.00$ & $0.00^{\mathrm{d}} \pm 0.00$ \\
\hline
\end{tabular}

Values are mean \pm standard deviation of duplicate samples ${ }^{a-d}$ Means with similar superscript are not significantly difference $(P>0.05)$

Note: S:P $(60: 40)=$ sorghum 60 : pigeon pea 40 S:P:C $(50: 20: 30)=$ sorghum 50 : pigeon pea 20 : carrot 30 S:P:C

$(50: 30: 20)=$ sorghum $50:$ pigeon pea $30:$ carrot 20

while cerelac had higher niacin, pyridoxine and cyanocobalamin contents. B-carotene contents $(7150$ and $7280 \mathrm{mcg} / 100 \mathrm{~g}$ respectively) of S:P:C (50:30:20 ; 50:20:30) were significantly higher than those of cerelac $(5220 \mathrm{mcg} / 100 \mathrm{~g})$ and S:P:C (60:40:0) (4930mcg/100g). Ascorbic acids and thiamin obtained for S:P:C 50:30:20 and $50: 20: 30$ were $4.27-4.78$ and $0.52-0.56 \mathrm{mg} / 100 \mathrm{~g}$ respectively, cerelac $(4.08$ and $0.50 \mathrm{~m} / 100 \mathrm{~g}$ respectively), $S: P: C \quad(60: 40: 0) \quad(3.48$ and $0.93, \quad 0.49 \mathrm{mg} / 100 \mathrm{~g}$ respectively). Tecopherol, riboflavin, niacin, pyridoxine and cyanocobalamin $(3.16,0.29,3.93$ and $0.24 \mathrm{mg} / 100 \mathrm{~g})$ were significantly higher in crelac than in the blends $(2.85$ $-2.91,0.19-0.24,0.34-3.61,0.40-0.50$ and $0.15-$ $0.18 \mathrm{mg} / 100 \mathrm{~g})$.

Phytochemical composition of the gruels from cerelac and sorghum, pigeon pea and carrot blends

The results of phytochemicals analysed are presented on Table 4. Flavonoids, phytate, oxalate and alkaloids were 
054 Afr. J. Food Sci. Technol.

Table 5. The Sensory attributes of the complementary food produced from sorghum, pigeon pea and carrot gruels

\begin{tabular}{|c|c|c|c|c|}
\hline Attributes & S:P(60:40) & S:P:C (50:20:30) & S:P:C (50:30:20) & Cerelac \\
\hline Taste & $5.00^{\mathrm{b}} \pm 1.78$ & $5.45^{b} \pm 1.85$ & $5.70^{b} \pm 1.34$ & $7.55^{\mathrm{a}} \pm 1.64$ \\
\hline Texture & $5.65^{\mathrm{b}} \pm 1.50$ & $5.75^{\mathrm{b}} \pm 1.52$ & $5.75^{\mathrm{b}} \pm 1.16$ & $7.75^{a} \pm 1.37$ \\
\hline Colour & $4.70^{c} \pm 1.22$ & $6.10^{\mathrm{b} \pm 1.45}$ & $6.45^{\mathrm{b}} \pm 1.32$ & $8.10^{\mathrm{a} \pm 1.12}$ \\
\hline Flavour & $6.00^{\mathrm{b}} \pm 1.34$ & $6.85^{\mathrm{b}} \pm 1.46$ & $6.05^{b} \pm 1.43$ & $7.85^{\mathrm{a}} \pm 1.35$ \\
\hline General Acceptability & $5.70^{b} \pm 1.42$ & $5.85^{b} \pm 1.63$ & $6.30^{\mathrm{b}} \pm 1.38$ & $8.00^{\mathrm{a}} \pm 1.17$ \\
\hline
\end{tabular}

Values are mean \pm standard deviation of duplicate samples

${ }^{a-d}$ Means with similar superscript are not significantly difference $(P>0.05)$

Note: S:P $(60: 40)=$ sorghum 60 : pigeon pea 40

S:P:C $(50: 20: 30)=$ sorghum 50: pigeon pea 20: $\operatorname{carrot} 30$

$\mathrm{S}: \mathrm{P}: \mathrm{C}(50: 30: 20)=$ sorghum 50 : pigeon pea $30:$ carrot 20

not found in cerelac. There were no significant differences on the tannin and flavonoid contents of blends with carrot flour. The values of flavonoids and tannins $(0.09$ and $0.07 \mathrm{mg} / 100 \mathrm{~g})$ in S:P:C $(70: 20: 10)$ and $S: P: C \quad(50: 30: 20)$ were significantly higher than values obtained for S:P:C (60:40:0). Phytate obtained in each of the blend was $0.05 \mathrm{mg} / 100 \mathrm{~g}$. Oxalate and alkaloid in the blends ranged between $0.02-0.03$ and $0.04-$ $0.06 \mathrm{mg} / 100 \mathrm{~g}$ respectively.

\section{Sensory attributes of the gruels from cerelac and sorghum, pigeon pea and carrot blends}

Sensory attributes of the products is presented on Table 5. Taste (7.55), texture (7.75), colour (8.10), flavor (7.85) scores for cerelac were significantly higher than the scores obtained for taste $(5.00-5.70)$, texture $(5.65-$ $5.75)$, colour $(4.70-6.45)$ and flavor $(6.00-6.85)$ for the blends.

\section{DISCUSSION}

Moisture was relatively high in all the products; this outcome was expected because the products were tested as eaten. Moisture is an index of the shelf life of any food. Moisture content of less than $10 \%$ has been reported to be responsible for the state of non-deterioration in food (Makkar et al., 1998); this implies that these products will be prone to spoilage once prepared, it therefore means that only amount that is to be consume at time that should be prepared as preparing excess with lead to spoilage and wastage.

Protein and fat obtained in the blends were significantly lower than those found in cerelac, fiber was significantly higher in S:P:C (50:30:20) while carbohydrate and energy were higher in S:P:C (50:30:20). When compared with a study carried out on malted cereals, soybean and groundnut (Anigo et al., 2010); the protein, fat, fiber, ash and carbohydrate obtained in this study were lower. It was observed that high proximate values reported in that study could be as a result of low moisture in that product. Moisture is a function of other proximate composition of any food product.

All the minerals obtained in the blends were significantly lower than those of the cerelac. The predominant minerals obtained in all the products were phosphorus, potassium and selenium. Other minerals obtained in substantial amount were magnesium and iodine. The phosphorus content of the blends though lower than that of cerelac can supply $77.45-78.54 \% \mathrm{RDI}$ need of children within the age bracket of $7-12$ months old. Phosphorus is an essential component of phospholipids, bones and teeth, its deficiency can lead to bone loss, weakness and loss of appetite (Oh and Uribarri, 2006); while potassium is known for its role in the stabilization of osmotic pressure and normal $\mathrm{pH}$ equilibrium of the body system (Oyarekua, 2009). Calcium obtained in this study was higher than the value $(2.0-6.05 \mathrm{mg} / 100 \mathrm{~g})$ reported for complementary food formulated made from millet, pigeon pea and seedless breadfruit (Mbaeyi-Nwaoha and Obetta, 2016) but lower than the value $(27.0-47.95 \mathrm{mg} / 100 \mathrm{~g})$ reported for complementary food formulated from malted cereals, soybeans and groundnut (Anigo et al., 2010). Higher calcium value reported in that study could be attributable to the form in which it was analysed; analysis done on dry weight bases are usually more concentrated in some nutrients than analysis done on wet bases. Children within $7-12$ months are expected to consume $270 \mathrm{mg} / \mathrm{d}$ of calcium (Warldlaw and Hampl, 2007). Inadequate of calcium intake results in rickets, stunting and biochemical signs of hyper thyroidism.

Micro minerals otherwise known as trace minerals are minerals needed in the body in less than $100 \mathrm{mg}$ per day. These minerals are dietary essentials because of their specified biological functions in the body; this implies that dietary deficiency can result in physiological or structural abnormalities (FNB, 1997; FNB 2000; FNB, 2001). The results of micro minerals shows that the products developed were good sources of Se, I and $\mathrm{Zn}$. The RDI of Se, I and $\mathrm{Zn}$ for children ages $7-12$ months $20 \mathrm{mcg} / \mathrm{d}$, $130 \mathrm{mcg} / \mathrm{d}$ and $3 \mathrm{mg} / \mathrm{d}$; this implies that the products will be able to supply over $100 \%$ Se daily need and $65.15-$ 71.69 iodine and 60.67 - $72.0 \%$ zinc daily need respectively of children of that age group. Apart from 
synthesizing thyroxine, iodine is essential for normal brain development; it also known to increase glucose utilization and protein synthesis. Zinc on the other hand contributes to DNA and RNA synthesis, protein metabolism and related growth and acid/base balance in the body (King and Cousins, 2006).

It was observed that the blends with carrot had significantly $\{p<0.05)$ higher $\beta$-carotene, ascorbic acid and thiamin than the blend made with sorghum with soybean alone and cerelac. Carrot is a good source of $\beta$ carotene; its addition in S:P:C (50:20:30 and 50:30:20) must have increased the amounts of the $\beta$-carotene value. $\beta$-carotene is known for its role in preventing cardiovascular disease in individuals at high risk (Osganian, 2003), $\beta$-carotene is also a vitamin A precursor. In its active form vitamin $A$ is significant action in biochemical or physiological action in vision, growth and development and immunity (FNB, 2001). Other vitamins obtained in reasonable amounts are thiamin, riboflavin and niacin. These vitamins play significant role in the metabolism of energy. Phytochemicals investigated were generally low; they were below $1 \%$. This implies that these phytochemicals were within the permissible level (Anigo et al., 2010).

Sensory evaluation showed that cerelac was more accepted in terms of colour, texture, taste and flavor. This outcome was however expected because the panelist are used to celelac. The result however revealed that the score for colour of blends with carrot were significantly higher than that of the blend without carrot. The presence of $\beta$-carotene may have enhanced the acceptability of the colour of the blends; carotenoids in foods are generally classified into carotenes and xanthophylls, these phytochemicals are known to give attractive red or yellow colour and also contribute to food quality (Shama et al., 2011).

\section{CONCLUSION}

Cerelac was a better source of protein, fat, and most of the mineral analysed. S:P:C (50:20:30) had the highest fiber, $\beta$-carotene, vitamin $\mathrm{C}$ and thiamin. No phytochemical was detected in cerelac; in the blends the value of each phytochemical analysed was below $1 \%$. Sensory evaluation showed that cerelac was generally more acceptable than the blends.

\section{REFERENCE}

Anigo KM, Ameh DA, Ibrahim S, Danbauch S (2010). Nutrient composition of commonly used complementary foods in North western Nigeria. Afri. J. n-Biotech 8(17): 4211-4216.

Association of Official Analytical Chemist AOAC.(2006). Official methods of analysis, association of official analytical chemistry,

Washington, D. C.

Brown $K H(1991)$. The importance of dietary quality version for weanlings in less developed countries. A framework for discussion. Food Nutr. Bull. 2: 86-93.
Eknayake S, Jansz E, Nair BM ( ) "Proximate composition, mineral and amino acid content of mature Conovalia gladiate seed. Food Chem. 66(1):115-119.

Food and Nutrition Board (FNB) (1997). Institute of Medicine: Dietary Reference Intakes for calcium, phosphorus, magnesium, vitamin D and fluoride. Washington DC, National Academy Press.

Food and Nutrition Board (FNB) (2000). Institute of Medicine: Dietary Reference Intakes for vitamin C, vitamin E, selenium carotenoids. Washington DC, National Academy Press

Food and Nutrition Board (FNB) (2001). Institute of Medicine: Dietary Reference Intakes for vitamin A, vitamin K, arsenic, boron, chromium, nikel, silicon, vanadium and zinc. Washington DC, National Academy Press

King JC, Cousins RJ(2006). Zinc In Shills M.E and others (eds): modern nutrition in health and disease. 10thed, Philadelphia, PA:Lippincott Williams and Wilkins.

Kirk R, Sawyer R(1998). Pearson's composition and analysis of foods. Church HillLivingstone, Edinburgh. Accessed January19th, 2019 from www.amazon.co.uk.

Lutter CK, Rivera J(2003). Nutritional status of infants and young children and characteristics of their diets. J. Nutrition.,133, 2941S 2949S.

Makkar HPS, Becker K(1996). Nutritional value and antinutritional component of and ethanol extracted Monringa oleifera. Animal Feed Science Technology. 63: 211-238.

Nnam NM, Odigwe NM(2007). Nutrient adequacy of complementary food formulated from blend of sprouted millet (Pennisetum glaucum), baobab seed (Adensonia digitata L.) and pulp from either baobab on mango (Magnifera indica L.) Nigerian Journal of Nutritional Sciences. 28(2): 121-126.

Nnam NM.(2002). Evaluation of Complementary Foods based on Maize, Groundnut, Pawpaw and Mango flour Blends. Niger. J. Nutr. Sci. 23: 8-18.

Oh MS, Uribarri J(2003). Electrolytes, water, an acid-balance. In Shils M.E and others (eds): Modern nutrition in health and disease. $10^{\text {th }}$ ed. Philadelphia, PA:Lippincott Williams and Wilkins.

Osganian SK(2003). Dietary carotenoids and risk of coronary artery disease. American J. Clin. Nutrition. 77:1890.

Oyarekua MA(2009). Co-fermentation of cassava/cowpea/carrot to produce infant complementary food of improve nutritional quality. Asian Journal of Clinical Nutrition. 1(3): 120-130.

Sharma SK, Anup GA, Radhakrishman J,Thapa L, Shrestha NR Pandel N, Gurung K, Maskey R, Budathoki A, Baral N, David $\mathrm{BD}$ (2011). Prevalence of hypertension, obesity, diabetes and metabolic syndrome in Nepal Int'l. J. Hypertensio. Pp 821-971.

Stadimayr B, Charrondiere UR, Enujiugha VN, Bayyili RG, Romric GB, Etel G, Fagbohoun Samb B, Addy $P$, Barikmo IB, Ouattara F, Oshaug A, Akinyele I, Annor GA, Bomfeh, K, Ene-Obong HN, Smith IF, Thiam I, Burlingame B(2012). West Africa Food Composition Table/ Table de composition des aliments d'Afrique de IOuest.Food Agriculture Organization of the United Nations. Rome Italy.

United Nation International Children Emergency Fund (UNICEF). (2009) Tracking progress on childhood andmaternal nutrition. UNICEF: New York.

Uvere PO, Attaugwu RI, Ngoddy POI (2009). Development of maizecowpea complimentary foods fortified pre-fermentation using foods rich in calcium, iron, zinc and vitamin A. Nigerian Journal of Nutritional Sciences. Pp 90-97.

Wardlaw GM, Hampl JS(2007). Perspectives in nutrition. $7^{\text {th }}$ ed.New York McGraw Hill. Pp 54-244. 